\title{
EKSISTENSI MUSLIM TIONGHOA DALAM GERAKAN PENDIDIKAN ISLAM DI MAKASSAR
}

\author{
Muh. Aswar \\ Pascasarjana UIN Alauddin Makassar \\ JL.H.M Yasin Limpo No. 36 Samata, Gowa \\ Email: muh.aswar271@gmail.com
}

\begin{abstract}
Abstrak
Studi ini difokuskan pada gerakan pendidikan Muslim Tionghoa di Kota Makassar yang ditinjau dari aspek penyelenggaraan pendidikan formal dan non formala di Kota Makssar. Hasil penelitan ini menujukkan bahwa gerakan pendidikan Islam Muslim Tionghoa Makassar meliputi: 1) Pendidikan Formal, Pendidikan formal yang didirkan oleh Muslim Tionghoa yaitu SDIT Muhammad Cheng Hoo Sul-sel yang terletak di Jalan Tun Abd Razak Gowa, namun saat ini belum berjalan karena masih proses pendirian gedung dan diprediksikan akan digunakan pada tahun 2021. 2) Pendidikan non formal diantaranya. (a) Pondok Tahfidzul Qur'an Muhammad Cheng Hoo Makassar Pondok ini terletak di jalan Tanjung Bayang Kota Makassar tepat disamping Masjid Muhammad Cheng Hoo Makassar yang berdiri pada bulan Agustus 2016, Program ini merupakan program Takmir masjid Muhammad Cheng Hoo Makasaar yang banyak diminati karena dilaksanakan tanpa pungutan biaya. Program ini bertujuan menciptakan generasi muda Qur'ani yang mampu menghafal dan mengamalkan al-Qur'an yang kedepannya diharapkan mencetak generasi-generasi yang mampu mengaktualisasikan ajaran-ajaran Islam yang terkandung didalam alQur'an. (b) Pendidikan dan pembinaan Muallaf ini dilaksanakan setiap pekan pada hari Jum'at pukul 13.30, tempat pelaksanaannya bergaintian antara masjid Muhammad Cheng Hoo Makassar dan Gowa, yang bertujuan agar saudara-saudara muslim yang baru belajar dan mendalami agama Islam dengan baik dan mantap, sekaligus sebagai wadah untuk menjaling silaturrahim sesama Muallaf.
\end{abstract}

Kata Kunci: Muslim tionghoa, pendidikan formal dan non formal muslim tionghoa

\section{PENDAHULUAN}

endidikan adalah salah satu bentuk interaksi manusia. Ia adalah suatu
tindakan sosial yang dimungkinkan berlakunya melalui suatu jaringan
hubungan-hubungan kemanusiaan. Jaringan-jaringan inilah bersama dengan
hubungan-hubungan dan peranan-peranan individu di dalam menentukan watak pendidikan di suatu masyarakat, sehingga hidup masyarakat berjalan dengan dinamis. ${ }^{1}$ Adanya kondisi kehidupan manusia yang dinamis yang ditandai dengan adanya kerjasama, akomodasi, akulturasi, dan asimilasi. Pada dasarnya, kondisi ini merupakan satu kontinum dari yang terendah sampai yang tertinggi keserasiannya. Suasana kebersamaan dalam kehidupan beragama dan bermasyarakat dalam masyarakat majemuk di Kota Makassar nampak dalam berbagai aktifitasnya.

${ }^{1}$ Hasan Langgulung, Asas-Asas Pendidikan Islam (Cet. VI Edisi Revisi; Jakarta: PT. Pustaka Al-Husna Baru, 2008), h. 16. 
Misalnya kerjasama sosial, dialog antar berbagai tokoh agama. Kota Makassar merupakan kota yang metropolitan, masyarakatnya majemuk dan beraneka ragam agama, suku, ras, etnis, dan antar golongan. Termasuk pula kebudayaan dan agamanya. Selain penduduk pribumi terdapat pula sejumlah penduduk etnis pendatang. Di antara etnis pendatang adalah etnis Tionghoa.

Etnis tionghoa yang beragama Islam di Kota Makassar memiliki peranan, baik di bidang ekonomi, pendidikan maupun di bidang keagamaan atau kepercayaan. Khusus pada bidang agama, etnis Tionghoa muslim memiliki kiprah dalam kegiatan pendidikan Islamiyah. Terbentuknya PITI (Persatuan Islam Tionghoa Indonesia) sebagai wadah bagi para keturunan Tionghoa yang beragama Islam menunjukan adanya sebuah usaha dari para leluhur China di Nusantara guna menjaga kegiatan dan tradisi religius di setiap darah keturunannya. Segala hal yang dilakukan guna menjaga eksistensi tersebut merupakan sebuah hal yang penting untuk dikaji. Mengingat mau tidak mau harus diakui bahwasannya etnis Tionghoa mempunyai andil besar dalam memperkaya khazanah ke-Islaman di negeri ini dan khususnya dikota Makassar. Dalam penelitian ini, penulis menitikberatkan penelitian pada komunitas muslim Tionghoa di Kota Makassar. Hal ini mempertimbangkan cukup besarnya jumlah keturunan etnis Tionghoa di Kota Makassar yang beragama Islam. Menurut Ketua PITI Sul-Sel Bapak Jhon Adam terdapat lebih dari 400 kepala keluarga Tionghoa yang beragama Islam. Di samping itu, fenomena China muslim di Makassar masih merupakan sesuatu yang bersifat minoritas, baik apabila hal tersebut dibandingkan dengan jumlah kaum muslim yang non-China maupun apabila dibandingkan dengan jumlah etnis China yang non-muslim. Itu artinya, etnis Tionghoa yang beragama Islam merupakan kelompok minoritas ganda, yakni minoritas dalam masyarakat muslim sekaligus minoritas dalam masyarakat etnis Tionghoa maupun dalam masyarakat muslim Makassar. Keteguhan untuk tetap berpegang teguh pada agama Islam yang diyakini oleh para anggota PITI Makassar meski dengan konsekuensi menjadi kaum minoritas, pada dasarnya merupakan hal yang patut untuk diapresiasi, terutama mengenai cara mereka menjaga kekompakan guna tetap menjalankan kegiatan dan tradisi religius bersama keturunan dan anggotanya. Hal tersebut terbukti dengan berdirinya dua Masjid yang bernuansa budaya Tionghoa di Sulawesi-Selatan yaitu di Kota Makassar tepatnya di Jalan Tanjung Bunga dan di Kabupaten Gowa tepatnya di Jalan Tun Abd Razak, bahkan mendirikan dua sekolah yakni Sekolah tahfidzul Qur'an tepat disamping Masjid Cheng Hoo Makassar, dan sekolah Islam terpadu di samping masjid Muhammd Cheng Hoo Gowa yang gedungnya masih proses pengerjaan. Dalam hal ini, mereka berdakwah, berkumpul, berdiskusi, bersilaturahmi, melakukan didikan terhadap para Muaalaf dengan mengadakan pengajian rutin setiap hari jum'at.

Masyarakat secara umum dan khususnya di kota Makassar belum mengetahui eksistensi Muslim Tionghoa di Kota Makassar, sehingga ada beberapa masyarakat 
yang kadang beranggapan bahwa kehadiran Muslim Tionghoa dengan mendirikan Masjid dan Fasilitas pendidikan baik itu sekolah tahfidz dan sekolah islam terpadu memiliki tujuan terselubung seperti halnya isu yang tengah beredar bahwa muslim tionghoa yang hadir disekitar kita adalah antek-antek orang Cina yang betujuan menguasai Indonesia baik dibidang pendidikan, perdagangan dan kebudayaan, dengan demikian ditakutkan terjadinya gesekan antara pribumi dengan Etnis Tionghoa Muslim seperti halnya tragedi Pa' Baeng-Baeng pada 15 September 1997 yang menewaskan sekitar 500 Orang lebih terluka dan peristiwa Toko La pada 10 April 1980 di jalan Gunung Merapi yang banyak menimbulkan kerugian.

Oleh karena itu, dalam pandangan penulis, penelitian Eksistensi Muslim Tionghoa dalam aspek gerakan pendidikan di Makassar, dalam hal ini dikonsentrasikan pada kegiatan pelaksanaan pendidikan formal dan nonformal Muslim Tionghoa di Kota Makassar sangat penting untuk dilakukan.

\section{METODE PENELITIAN.}

Dalam menganalisis data, penulis menelaah seluruh data yang tersedia dari berbagai sumber, yaitu pengamatan yang sudah dituliskan dalam catatan lapangan, wawancara, dan dukumen pendukung. analisis data dalam penelitian ini dilakukan dalam tiga cara, yaitu: reduksi data, display data, kesimpulan dan verifikasi.

Jenis penelitian yang digunakan dalam penelitian ini adalah penelitian kualitatif deskriptif dengan mengambil lokasi dan objek penelitian pada penyelengaraan pendidikan Muslim Tionghoa di Kota Makassar.

\section{HASIL DAN PEMBAHASAN}

\section{A. Bentuk dan Tujuan Gerakan Pendidikan Islam Muslim Tionghoa di Makassar}

PITI merupakan organisasi nasional Muslim Tionghoa, olehnya itu dalam rangka mewujudkan tujuan dan cita yang terstruktur dan terkultur PITI Sulawesiselatan membentuk Yayasan Muhammad Cheng Hoo Sulawesi-selatan, yayasan Muhammad cheng Hoo Sulawesi selatan dibentuk dan diakui secara formal pada tahun 2010.

Setelah terbentuk yayasan Muhammad Cheng Hoo Sulawesi-selatan medirikan Masjid Muhammad Cheng Hoo Gowa yang terletak di jalan Tun Abd Razak gowa pada tahun 2011 dan Masjid Muhammad Cheng Hoo Makassar dan gedung asrama program tahfidzul Qur'an pada tahun 2014 di jalan Tanjung bunga Makassar sebagai pusat aktivitas sosial dan ibadah Muslim Tionghoa Sulawesi-selatan, Ketua pertama yayasan Muhammad Cheng Hoo Sulawesi-selatan bernama Drs Sulaiman Gosalam M.Si beliau juga pernah menjabat sebagai ketua PITI Makassar dan Sulawesi-selatan, kemudian diganti oleh bapak Ahmad Fran Sudictar debagai ketua yayasan Muhammad Cheng Hoo Sulawesi Selatan pada tahun 2017 yang lalu, saat ini kantor yayasan 
Muhammad Cheng Hoo Sulawesi selatan berpusat di Jalan Tun Abd Razak Gowa tepatnya di gedung Masjid Muhammad Cheng Hoo gowa.

Tepat pada tanggal 17 Juli 2017, Yayasan Muhammad Cheng Hoo Sulawesiselatan melakukan peletakan batu pertama untuk pendirian sarana pendidikan Islam terpadu tepatnya di Jalan Tun Abd Razak Gowa, sarana pendidikan ini direncanakan akan digunakan sebagai pelaksanaan pendidikan formal yakni Sekolah Dasar Islam Terpadu (SDIT).

Pada penelitian tentang "Eksistensi Muslim Tionghoa dalam Gerakan Pendidikan Islam di Makassar" ini penulis memfokuskan pada gerakan pendidikan formal dan nonformal.

\section{Pendidikan Formal}

Muslim tionghoa kota Makassar sangat aktif dalam menyelenggarakan pendidikan diantaranya adalah keinginan untuk mendirikan gedung sarana pendidikan formal yang dinaungi oleh yayasan Muhammad Cheng Hoo Sul-sel yang bertempat di Kabupaten gowa tepatnya dijalan Tun Abd Razak Hertasning, hanya saja penulis belum bisa menggali terlalu dalam mengenai aktivitas sekolah formal ini karena belum terlaksana, diprediksikan sekolah formal ini akan berjalan pada tahun 2021 M, Gedung ini direncanakan untuk fasilitas sekola dasar Islam terpadu (SDIT) yang diberi nama SDIT Muhammad Cheng Hoo Sul-Sel, untuk saat ini gedung pendidikan tersebut masih proses pengerjaan lantai 1 dan direncanakan akan dibangun sebanyak 4 lantai yang diprediksikan menghabiskan kurang-lebih 15 Milliar dana.

Dengan adanya sarana pendidikan Islam tepadu ini diharapkan generesigenerasi para Muallaf dan Muslim Tionghoa memiliki wadah untuk mengembangkan dan menigkatkan keimanan dan wawasan mereka, sehingga anak-anak mereka tidak kesekolah-sekolah lain sebagai sehingga sebagai generasi Muallaf ataupun tionghoa bisa terarah dalam mengenal Islam ${ }^{2}$

Tujuan dari pendirian ini supaya kita bisa mengkader ya, generasi muda selaku penerus dengan pendidikan Islam yang terpadu, ini sangat penting karena lewat pendidikanlah kita dapat membentuk kaarakter dari semua anak didik kita, disitu Islam terpadu bukan hanya kurikulum pendidikan umum tapi yang Islami, jadi ada tahfidz, ada juga bahasa mandarinnya, bahasa arab jadi begitu. ${ }^{3}$

Terkait dengan pola manajemen sekolah ini bapak Abdul halim selaku sekertaris panitia pembangunan mengatakan: Dalam mengembangkan sarana pendidikan ini rencananya akan diatur dengan cara subsidi silang bagi yang mampu dan kurang mampu, dan pastinya akan ada kebijaksanaan tesendiri bagi umat yng ingin menyokolahkan anaknya di sini bagi yang kurang mampu, dan untuk sekarang ini

\footnotetext{
${ }^{2}$ Abdul Halim (40 Tahun), Sekretaris panitia pembangunan SPIT Muhammad Cheng Hoo Sulsel, Wawancara, Makassar pada tanggal 03 Oktober 2018

${ }^{3}$ Sulaiman Gosalam (49 Tahun), Ketua PITI Pertama Makassar, Wawancara, Makassar pada tanggal 05 Oktober 2018
} 
belum ada manajemen yang ditetapkan mengenai pengelolaan sekolah ini karena untuk sementara masih ditangani oleh panitia pembangunan. ${ }^{4}$

Dana yang digunakan untuk pembangunan ini bersal dari sumbangsi PITI (Persatuan Islam Tionghoa Indonesia), PSMTI, perusahaan-perusahaan Swasta dan banyak pula sumbangsi dari masyarakat pribumi utamanya jamaah masjid Muhammad Cheng Hoo. Gedung pendidikan ini juga akan digunakan untuk bimbingan Islam dan asrama bagi para muallaf, karena terkadang ada diantara saudara-saudara yang telah masuk Islam mereka diusir dari keluarga olehnya itu mereka membutuhkan tempat untuk sementara sembari memperdalam dan memantapkan pemahaman tentang Islam. Gedung ini juga akan digunakan untuk belajar bahasa mandarin (China), yang rencananya akan dibuka untuk siapa saja yang ingin belajar bahasa Mandarin dan bukan terkhusus untuk warga Thiong Hoa, karena diprediksikan hubungan ekonomi akan semakin meningkat dengan negara China olehnya itu anak-anak muda harus mahir berbahasa China atau Mandarin sebagai sarana untuk berkomunikasi dengan mereka.

\section{Pendidikan Non Formal}

Pendidikan non formal yang diselenggarakan oleh Muslim Tionghoa Makassar diantaranya, Sekolah tahfidzul qur'an, Bimbingan Islam Intensif, Pembelajaran Bahasa Arab, Dzikir Malam Jum'at dan Tahsinul qiro'ah. pada pendidikan non formal ini penulis memfokuskan pada dua item yakni sekolah tahfidzul Qur'an dan bimbingan Islam intensif.

a) Tahfidzul Qur'an.

1) Tujuan

Tahfidzul Qur'an ini merupakan program Takmir masjid Muhammad Cheng Hoo Makassar, yang gedungnya terletak dijalan Tanjung Banyang tepatnya disamping gedung Masjid Muhammad Cheng Hoo Makassar, gedung Tahfidzul Qur'an ini terdiri atas dua lantai yang digunakan untuk asrama santri dan Pembina sementara proses pengajaran dilaksanakan di gedung Masjid Muhammad cheng Hoo Makassar.

Program ini bertujuan ingin menciptakan generasi muda Qur'ani yang bukan hanya mampu menghafal al-Quran tapi yang terpenting adalah bagaimana mengamalkan al-Qur'an, jadi untuk menghafal dan mengamalkan. Diharapkan kedepannya muncul generasi-generasi yang berimban ya, karena mengingat sekarang tantangan-tantangan generasi pemuda islam sangat luar biasa ya, jadi perlu dibentengi dengan pendidikan agama dan pendidikan al-Qur'an, coba kita lihat sekarang tantangan narkoba kemudian pergaulan bebas kalau tidak didekatkan dengan al-Qur' an bisa-bisa hancur kedepannya. ${ }^{5}$

\footnotetext{
${ }^{4}$ Abdul Halim (40 Tahun), Sekretaris panitia pembangunan SPIT Muhammad Cheng Hoo Sulsel, Wawancara, Makassar pada tanggal 03 Oktober 2018

${ }^{5}$ Badaruddin Basir (38 tahun), Sekretaris Masjid Muhammad Cheng Hoo Makassar "Wawancara", Makassar pada tanggal 28 September 2018
} 
Program Tahfidzul Qur'an Muahammad Cheng Hoo ini dimulai sejak tahun 2016 yang dibina oleh enam orang Guru Tahfidzul Qur'an, jumlah santri sebanyak 30 Orang yang datang dari berbagai kota dan kabupaten diantaranya Makasar, Gowa, takalar, Sidrap, Pare-pare, maros, sengkang bahkan ada yang berasal dari jawa timur. Banyak masyarakat yang ingin memasukkan anaknya di program ini hanya saja karena kuota yang terbatas sehinnga mereka cenderung diarahkan ke pondok Tahfidzul Qur'an lain seperti Pondok Tahfidzul Qur'an dibarombong Makassar.

Santri-santri yang dibina pada program ini merupakan siswa-siswa yang duduk dibangku Tsanawia yang telah diberikan ijin untuk focus menghafal dan saat pelaksanaan ujian nasional mereka juga diikutkan, olehnya itu selain proses menghafal santri juga dibekali seperti pembelajaran bahasa arab, pembelajaran kaligrafi dan ilmuilmu lain yang dianggap penting.

2) Penaggung jawab

Adapun struktur penanggung jawab program Tahfidzul Qur'an yaitu :

$\begin{array}{ll}\text { Koordinator } & \text { :Ustadz Legiran, S.Pd } \\ \text { Sekretaris } & \text { :Ustadz Takdir } \\ \text { Bendahara } & : \text { Ustadzah Ummu saadah } \\ \text { Pembina Asrama: } & \\ & >\text { Ustadz Hasbi Hakim, S.Pd } \\ & >\text { Adi Perdana, S.Ei } \\ & >\text { Ustadz Agus Ramhadhani } \\ & >\text { Ustadz Mujahidin, S.Pd,. M.Pd }\end{array}$

3) Proses dan jadwal

Pukul 03.30 :Bangun Shalat Tahajjud dan menghafal

Pukul 05.00 :Shalat Subuh berjamaah dan menyetor hafalan

Pukul 06.20 : : Dzikir Pagi, Belajar bahasa Arab, dan kaligrafi (hari selasa)

Pukul 07.00 :Sarapan Pagi, mandi, mencuci/beres-beres asrama

Pukul 0815 :Shalat Duha dan lanjut menghafal

Pukul 09.30 : Istrahat

Pukul 10.00 : Muroja'ah/mengulang hafalan

Pukul 11.00 :Belajar bahasa Arab, Kaligrafi (Hari selasa)

Pukul $12.00 \quad$ :Shalat Dzuhur

Pukul 12.30 :Makan siang

Pukul 13.00 : Muroja'ah/mengulang hafalan

Pukul 14.00 :Istirahat/tidur siang

Pukul 15.15 :Shalat Ashar

Pukul 15.30 :Menghafal

Pukul 16.30 :Olah raga

Pukul 17.30 :Persiapan ke masjid

\footnotetext{
${ }^{6}$ Legiran (27 Tahun, Koordinator Program Tahfidzul Qur'an Masjid Muhammad Cheng Hoo makassar "Wawancara", Makassar pada tanggal 03 Oktober 2018
} 
Pukul 18.00 :Shalat magrib dan lanjut Taklim

Pukul 19.15 : :Shalat Isyah lanjut makan malam dan lanjut menghafal

Pukul $22.00 \quad$ :Tidur malam. ${ }^{7}$

4) Perbedaan dengan pondok Tahfidzul Qur' an lain

Secara umum pondok Tahfidzul Qur'an Muhammad Cheng Hoo Makassar hampir sama dengan pondok Tahfidzul Qur'an lain, namun pondok Tahfidzul Qur'an Muhammad Cheng hoo Makassar berusaha dan berupaya tidak membebani santrisantri pembayaran pembinaan dan lain-lainnya, fasilitas dan sarana sangat memadai olehnya itu pondok Tahfidzul Qur'an Muhammad Cheng Hoo banyak diminati oleh Masyarakat, selain itu para santri juga dibekali beberapa pelajaran diantaranya bahasa Arab dan membuat kaligrafi. ${ }^{8}$

Menurut Zulhaq, sala satu santri program Tahfidzul Qur'an Masjid Muhammad Cheng Hoo Makassar yang merupakan utusan dari pesantren Hasan Yamani Bone.

Alhamdulilla, karena waktu saya menghafal di Syekh Hasan Yamani, kan disana sistem menghafal itu kurang kuat karena tidak di Khusukan kita juga dengan pelajaran-pelajaran umum, tapi Alhamdulillah selama pinda kemari, kalau untuk menghafal bisa lebih fokus dan khusus, bisa dibilang kayak Alhamdulillah nikmat betul dan bisa lebih konsentrasi, dan kalau di sini makan, minum, listrik semua ditanggung tapi mungkin anak-anak disini dukumpulkan biaya 80 ribu perbulan karena mungkin untuk kegiatan seperti hari sabtu, kita ikut bimbel dijalan Bonto Lempangan jadi transportasinya bisa digunakan dari anak-anak atau mungkin setiap 2 Pekan sekali keluar main futsal dan kegiatan lainnya ada pergi keacara-acara, jadi dana 80 ribu dari setiap santri itu, itu yang dipakai untuk kegiatan, ada juga seperti kekurangankekurangan asrama kita bisa pakai untuk memenuhi kekurangan. ${ }^{9}$

5) Sumber Dana

Sudah suatu keniscayaan bahwa setiap rutinitas, program dan kegiatan membutuhkan dana, sumber utama dana yang digunakan dalam Tahfidzul Qur' an yaitu dari sumbangsi para muslim tionghoa (PITI) dan Ibu Ramala Kalla yang telah menjadi donator tetap pelaksanaan kegiatan Tahfidzul Qur'an, dan juga dari celengan pekanan masjid Muhammad Cheng Hoo Sulawesi-selatan bahkan pernah juga mendapat bantuan dana sebanyak dua kali dari Raja Kelantang dan Pangeran kelantang Malesia. $^{10}$

Untuk sekolah tahfidz itu untuk pembinaan itu sekitar dua belas juta diluar makanan, dan kalau diperkirakan untuk makanan itu sekitar sepuluh juta la untuk santri

\footnotetext{
${ }^{7}$ Legiran (27 Tahun, Koordinator Program Tahfidzul Qur'an Masjid Muhammad Cheng Hoo makassar "Wawancara", Makassar pada tanggal 03 Oktober 2018

${ }^{8}$ Badaruddin Basir (38 Tahun), Sekretaris Masjid Muhammad Cheng Hoo Makassar "Wawancara", Makassar pada tanggal 28 September 2018

${ }^{9}$ Zulhaq (16 Tahun), Santri Program tahfidzul Qur'an Masjid Muhammad Cheng Hoo Makassar "Wawancara", Makassar pada tanggal 04 Oktober 2018

${ }^{10}$ Badaruddin Basir (38 Tahun), Sekretaris Masjid Muhammad Cheng Hoo Makassar "Wawancara", Makassar pada tanggal 28 September 2018
} 
dan Pembina. ${ }^{11}$ Program sekolah tahfidzul Qur'an ini dalam sebulan menghabiskan biaya sekitar dua puluh dua juta dalam sebulan.

\section{Pendidikan dan pembinaan Muallaf}

PITI Sulawesi-selatan membawahi dua Masjid yakni Masjid Muhammad Cheng Hoo Makassar dan Masjid Muhammad Cheng Hoo Gowa olehnya maka dari itu pendidikan dan pembinaan intensif bersama Muallaf dilaksanakan secara bergantian yakni kadang di Masjid Muhammad Cheng Hoo Makassar dan kadang di masjid Muhammad cheng Hoo Gowa.

Pendidikan dan pembinaan Islam intensif bersama Muallaf ini merupakan agenda pekanan Takmir masjid Muhammad Cheng Hoo Makassar yang telah berjalan sejak terbentuknya PITI di Sulawesi selatan bahkan program ini merupakan program wajib bagi Takmir Masjid Muhammad Cheng Hoo Makassar, mengingat semakin banyaknya saudara-saudara kita dari agama Kristen, Hindu, Budha dan Konghucu beralih atau masuk kedalam agama Islam, hampir setiap bulan ada muallaf yang di Islamkan di masjid Muhammad Cheng Hoo Makassar.

a) Tujuan

Program ini bertujan agar saudara-saudara muslim yang baru ini dapat sebisa mungkin belajar dan mendalami agama Islam dengan baik dan mantap, sekaligus sebagai wadah untuk menjaling silaturrahim sesama Muallaf. ${ }^{12}$

Seringkali pemahaman yang muncul di masyarakat adalah selesai bersyahadatnya seorang mualaf merupakan tujuan akhir. Hal tersebut tentu keliru, pasalnya butuh proses lebih dari itu mereka harus dibimbing, dijaga, dan dlindungi. Tidak hanya cukup pada syahadat, ada mualaf yang menghadapi persoalan dengan keluarganya. Ada juga yang terhimpit masalah ekonomi karena keluar dari pekerjaannya. Karena itu, prosesi pembinaan mutlak dibutuhkan.

b) Proses dan Pelaksanaan Pembinanaan.

Pembinaan Islam terhadap muallaf dilaksanakan setiap hari Jum'at jam 13.30-15-30 (Ashar), tempat bergantian setiap pekan antara masjid Muhammad Cheng Hoo Gowa dan Masjid Muhammad Cheng HooMakassar, para peserta pembinanaan ini tidak hanya diikuti oleh para Muallaf bahkan ada dari masyarakat setempat yang telah Islam sejak lahir, karena ingin menamba ilmu dan pengetahuan tentang islam.

Orang yang mengalami konversi agama bagaikan orang yang masuk rumah baru. Ia perlu diperkenalkan dengan situasi dan kondisi rumah barunya itu supaya, selain dapat menyesuaikan diri dengan situasi dan kondisi baru, juga dimaksudkan dapat mengatasi segala keadaan sesuai dengan tuntutan keadaan baru itu. Tidak sedikit orang yang mengalami konversi agama masih tetap berada pada sikap dan perilaku sesuai dengan konsep agama lama yang dipeluknya, dan belum bisa merubahnya sesuai dengan konsep agama barunya.

\footnotetext{
${ }^{11}$ Sufianto (27 Tahun), Pembina Santri Program tahfidzul Qur'an Masjid Muhammad Cheng Hoo Makassar "Wawancara", Makassar pada tanggal 04 Oktober 2018

${ }^{12}$ Muhammad Zain Fong (41 Tahun), Ketua Umum Masjid Muhammad Cheng Hoo Gowa"Wawancara", di Makassar pada tanggal 28 September 2018
} 
Pendidikan dan bimbingan bagi para muallaf ini ditekankan pada masalah bagaimana mereka dapat menjalankan ajaran agamanya, terutama yang berhubungan dengan kewajiban individual, agar para muallaf dapat menjalankan ajaran agamanya dengan baik. Karena mereka banyak yang berangkat dari pengetahuan yang kosong tentang keIslaman, maka pendidikan dan bimbingan bagi para muallaf bukan hanya dianjurkan bahkan menjadi kewajiban untuk diikuti, kecuali atas pertimbangan-pertimbangan tertentu. Tapi mereka diharapkan dapat mempelajari sendiri dan mendalami Islam pada pihak lain atau secara otodidak. Bimbingan ini diberikan bukan hanya untuk "mencuci" konsep-konsep lamanya, tetapi juga untuk mengisinya dengan konsep-konsep dan keimanan yang baru. Dengan demikian diharapkan mereka lebih mantap terhadap agamanya barunya dan merasa lebih betah berada di dalamnya, kerena mereka mendapatkan perhatian. Boleh jadi mereka akan kembali ke tempat asalnya bila tidak mendapatkan bimbingan yang intensif.

c) Materi pendidikan dan bimbingan muallaf

Adapun materi pendidikan dan bimbingan muallaf yang diterapkan pada pendidikan dan pembinaan Muallaf ini, yaitu memberikan pelayanan baik bagi saudara muslim yang baru mendapatkan hidayah, maka pendidikan dan pembimbingan diusahakan agar mampu memberikan sesuatu yang dibutuhkan bagi keperluan seseorang yang baru memeluk Islam. Materi itu dihimpun dari bahan-bahan yang memungkinkan muallaf untuk mampu mengetahui, memahami, dan mengamalkan ajaran Islam secara baik dan benar

1) Pembinaan aqidah Islamiyah

Pembinaan aqidah Islamiyah ini diharapkan dapat memupuk keimanan kepada Allah SWT. Secara mantap dan mengakar dalam diri sanubari masing-masing muallaf, dengan membersihkan jiwanya dari itiqad-itiqad yang mentuhankan sesuatu selain Allah SWT. Ikrar hanya merupakan pintu masuk ke dalam Islam, dan belum disebut mu'min bila akar aqidahnya belum benar sesuai dengan tuntutan Islam. Pada fase ini mullaf dituntun untuk memahami konsep aqidah, minimal makna yang terkandung dalam dua kalimat syahadah yang diucapkan ketika ikrar. Untuk mendapatkan pengetahuan konsep aqidah yang lebih komprehensif, maka materi-materi yang disajikan kapada muallaf dapat disebutkan sebagai berikut :

2) Pemahaman dasar Islam, meliputi: status dan peran agama Islam, fungsi agama Islam, perbedaan antara agama Samawi dan agama Budaya (Ardi), keunggulan agama Islam, tanggung jawab seorang muslim terhadap Islam, kalimat thayyibah, ketuhanan, kemanusiaan, kealaman, rukun iman, rukun Islam dan Thariqah lil iman

3) Prinsip dasar Islam

- Hal-hal yang berkaitan dengan Dzat Allah, seperti : Dzat Tuhan, sifat Tuhan, namanama Tuhan, ciptaan Tuhan dan kehendak Tuhan.

- Hal-hal yang berkaitan dengan eksistensi manusia, seperti : asal usul manusia, proses kejadian manusia, penciptaan manusia, untuk apa manusia diciptakan, apa pegangan hidup manusia, siapa tauladan hidup manusia, apa tujuan hidup manusia.

- Hal-hal yang berkaitan dengan Alam, seperti : alam gaib dan alam syahadah.

- Hal-hal yang berkaitan dengan eksistensi hidup, seperti : hidup di dunia dan hidup di akhirat. 
- Hal-hal yang berkaitan dengan nilai hukum (taklifi), seperti : wajib, sunnah, mubah, makruh, hara. Materi-materi lebih merupakan korelasi bahkan integrasi dengan materi keIslaman yang lain dalam arti bahwa dalam penyajian materimateri ini belum dituntut pilahnya antara aqidah dengan materi yang lain seperti, syariah dan akhlaq.

d) Pelatihan Praktik Ibadah

Untuk kepentingan ibadah praktis, materi yang dipilih oleh para pembimbing muallaf Tolotang, meliputi :

1) Taharah, meliputi : cara mandi, wudhu dan tayammum

2) Ibadah Shalat, meliputi: shalat wajib, rukun shalat, syarat sahnya shalat, waktu shalat, shalat Jumat, batalnya shalat.

3) Puasa, meliputi : puasa wajib, puasa sunnat, rukun puasa, syarat sahnya puasa, batalnya puasa, uzur puasa.

Materi-materi tersebut adalah materi yang bersangkut paut dengan kewajiban sehari-hari yang akan selalu ditemui dalam kehidupan muallaf, sehingga materi itu bersifat umum. Pendidikan dan pembinaan yang dilakukan oleh Bapak Drs. Sulaiman Gosalam M.Si dan Ustad Badaruddin Basir ,S.Ag.

e) Baca Al-Qur'an

Pembinaan muallaf dilakukan pula dengan mengajarkan Membaca Al-Qur'an. Program pengajaran ini diadakan dengan pemberian materi yang sederhana dan mudah dimengerti. Pengajaran tersebut sebagai bekal bagi para muallaf ketika akan mempelajari Islam lebih lanjut, mengingat suatu ketika mereka harus memperdalam sendiri ajaran agama Islam yang dipeluknya. Dengan bekal yang diterimanya ini diharapkan mereka paling tidak sudah dapat membaca Al-Qur' an sebagai kitab suci dan sumber ajaran Islam itu diambil, serta dasar ajaran itu diukur dan dikembalikan. Kemahiran membaca Al-Qur'an mengindikasikan kearifan atau kealiman ilmu agama yang dipeluknya, yang pada gilirannya dapat meningkatkan penghayatan terhadap ajaran-ajaran Islam.

f) Dialog Ke-Islaman dan Keagamaan

Dialog keIslaman ini senantiasa dilakukan oleh para pembimbing dengan maksud untuk mengkaji apakah materi-materi yang telah diberikan sebelumnya dapat dipahami dan dimengerti. Yang dijadikan sebagai bahan dialog tidak terlepas dari pada materi yang telah diberikan sebelumnya. Biasanya mereka sangat antusias menghadiri dialog keagamaan saat para pengurus masjid menghadirkan pembicara seperti Ustadz Felix Syiau seperti pada Akhir Tahun 2017 lalu. ${ }^{13}$

g) Sumber Dana

Dana yang digunakan untuk menjalankan program ini berasal dari PITI, dana masjid, dan infaq dari peserta yang memiliki materi yang lebih.

B. Tantangan dan Peluang Gerakan Pendidikan Islam Muslim Tionghoa di Makassar 1. Tantangan gerakan pendidikan Islam Muslim Tionghoa di Makassar

\footnotetext{
${ }^{13}$ Muhammad Zain Fong,’Wawancara”, di Makassar pada tanggal 05 Oktober 2018
} 
Hampir semua organisasi atau lembaga manapun memiliki hambatanhambatan dan dukungan. seakan hal tersebut sudah menjadi hukum kausalitas yang dialami oleh setiap lembaga, demikian juga dengan muslim Tionghia di Kota Makassar. Tantangan dalam pelaksanaan kegiatan dakwah DPD PITI Kota Makassar adalah sebagai berikut:

a) Tantangan Tahfidzul Qur'an

1) Masih berbentuk Non formal

Saat ini satri-santri yang modok pada Tahfidzul Qur'an Muahammad Cheng Hoo adalah santri yang mendapatkan izin dari sekolah didaeranya masing-masing untuk mondok, salah satu progress kedepannya yakni membentuk Tahfidzul Qur'an Muhammad Cheng Hoo menjadi Tahfidzul Qur'an yang formal sehingga para santri bisa lebih nyaman menjalankan rutinitasnya sebagai santri. Para Takmir masjid juga akan mengupayakan agar para alumni pondok Tahfidzul Qur'an mendapatkan bantuan BA siswa agar santri dapat melanjutkan studinya diperguruan tinggi. ${ }^{14}$

2) Ruangan Asrama yang terbatas

Saat ini pondok Tahfidzul Qur'an Muhammad Cheng Hoo Makassar peminatnya sangat banyak tetapi daya tampung masih kurang, melihat tantangan ini takmir Masjid sementara berupaya memikirkan jalan keluar dari tantangan ini.

b) Tantangan Pembinaan Islam Intensif Bersama Muallaf

1) Pembinaan muallaf bersifat eksperimental dan learning by doing.

Artinya, pembina muallaf mengelola pembinaan dengan tidak tetap dan berubah-ubah sesuai dengan kondisi dalam hal ini materi yang dibawakan oleh Pembina belum terstruktur dengan baik karena belum adanya kurikulum pembelajaran untuk muallaf yang ditetapkan sebagai pedoman. ${ }^{15}$

2) Belum adanya asrama tetap bagi Muallaf

Asrama sangat penting dalam pembinaan muallaf, karena menjadi tempat untuk mereka yang tidak mempunyai keluarga setelah memeluk Islam, bahkan bagi mereka yang diusir oleh keluarganya yang tidak menerima mereka meninggalkan agama leluhurnya.

3) Kurang hadir saat pembinaan

Problematika ini menjadi hal yang lumbar saat melaksanakan kegiatan, para Muallaf kadang yang sudah disibukkan kembali oleh pekerjaannya kadang tidak punya waktu luang lagi untuk menghadiri pembinaan, terkadang diantara mereka hanya hadir 1-2 kali sebulan padahal seharusnya hadir sebanyak 4 kali dalam sebulan.

4) Terkucilkan oleh Keluarga non Islam

Muallaf s ecara umum dan Kususnya Muslim etnis Tionghoa dipandang sebelah mata oleh kalangan mereka sendiri karena dianggap masuk Islam mengakibatkan ekonomi mereka lemah. Apalagi, anggapan miring itu semakin diperparah dengan tindak terorisme yang dituduhkan ke Islam. Beberapa bentuk persepsi keliru, yaitu sebagai berikut:

\footnotetext{
${ }^{14}$ Badaruddin Basir,"Wawancara”, di Makassar pada tanggal 05 Oktober 2018

${ }^{15}$ Muhammad Zain Fong,"Wawancara", di Makassar pada tanggal 05 Oktober 2018
} 
(a) Rasa takut dan malu dari pihak Tionghoa jika mengaku sebagai seorang Muslim, ketakutan akan dikucilkan keluarga, diputus dari jaringan keluarga dann iklim pemerintahan yang juga menambah rasa ketakutan itu. Malu karena derajatnya menjadi turun jika masuk Islam dan melebur dengan pribumi, sehingga ia tidak mau dikatakan orang Islam.

(b) Karena masih adanya orientasi yang kuat dengan tanah leluhur. Maka masih ada warga Tionghoa yang berpendapat "meskipun saya sudah masuk Islam, Cina ya tetap Cina"

(c) Masih adanya warga Tionghoa muslim yang tidak mau atau enggan bergaul dengan masyarakat Islam pada umumnya.

Selain itu, stigma buruk dari kalangan Tionghoa non-muslim sangat sulit dihilangkan, khususnya mereka yang berada pada level menengah ke atas, hidup secara eksklusif, dan kurang bergaul dengan penduduk setempat. Bahkan memandang rendah orang du luar komunitasnya. Mereka umumnya adalah orang- orang Tionghoa yang mempekerjakan orang-orang setempat (bugis-Makassar), dan tidak jarang mereka diperlakukan layaknya seorang pembantu. Oleh karena itu, muslim etnis Tionghoa harus mampu membuktikan persepsi miring itu salah.

\section{Peluang gerakan pendidikan Islam Muslim Tionghoa di Makassar}

Hadirnya Muslim tionghoa Makassar ditengah-tengah masyarakat dan setiap tahun mengalami bertambahan menjadi kebanggaan tersendiri bagi masyarakat muslim kota Makassar secara umum, kehadiran mereka disambut baik oleh masyarakat bahkan sangat mendukung program-program yang dilaksanakan oleh Muslim tionghoa Makassar. Berdirinya sarana ibadah yang terbuka umtuk umum seperti Masjid, memberikan kemudahan bagi masyarakat karena tidak repot untuk shalat ditempat yang jauh bahkan tidak jarang masyarakat mendapatkan pekerjaan dari masjid atau sarana ibadah yang didirikan oleh Muslim tionghoa sebagai petugas kebersihan, parkir bahkan sebagai petugas keamanan. ${ }^{16}$

Eksistensi seorang muslim Tionghoa sekarang ini jelas telah mendapat tempat tersendiri bagi Tionghoa non-muslim. Selain karena mereka sebagai etnis yang sama, muslim Etnis Tionghoa juga merupakan komunitas yang telah banyak berkiprah di berbagai bidang, khususnya kegiatan social kemasyarakatan diantaranya:

a. Program Tahfidzul Qur'an.

1) Program tanpa beban biaya

Hadirnya Muslim Tionghoa ditengah-tengah Masyarakat pribumi, menjadi angin segar bagi penduduk setempat dengan terlakananya program Tahfidzul ini tanpa membebani biaya bagi para santri yang mondok untuk menghafal.

2) Donatur tetap

Program tahfidzul qur'an ini dibantu oleh Ibu Ramlah Aqsa beliau merupakan donator tetap untuk pelaksanaan program tahfidzul Qur'an ini yang telah berlangsung kurang lebih dua tahun dan juga dari PITI Makasassar.

b. Pendidikan dan pembinaan Muallaf

\footnotetext{
${ }^{16}$ Muhammad Zain Fong,"Wawancara”, di Makassar pada tanggal 05 Oktober 2018
} 
1) Dilaksanakan oleh Muallaf.

Hadirnya pendidikan dan pembinaan Muallaf yang dilaksanakan oleh Muslim Tionghoa menjadi alternatif dan memberikan ciri khas karena umumnya yang menjalankan program ini adalah para Muallaf itu sendiri khususnya Muslim tionghoa, olehnya itu para muallaf yang baru masuk Islam tidak ragu-ragu untuk berbaur dan berproses pada program ini bahkan pemateri dalam hal ini adalah dari Muallaf itu sendiri.

2) Pendidikan dan pembinaan dilaksanakan secara gratis.

Banyaknya Muallaf-muallaf yang berekonomi menegah keatas y masuk Islam, banyak memberikan bantuan dalam menjalankan program ini utamanya dari PITI itu sendiri, sehingga untuk memenuhi kebutuhan pelaksanaan peserta tidak dibebani biaya.

\section{Pendapat Masyarakat Pribumi Tentang Gerakan Pendidikan Islam Muslim Tionghoa di Makassar}

Hadirnya Muslim Tionghoa ditenga-tengah masyarakat pribumi dengan membentuk organisasi PITI yang kemudian turut andil dalam kegiatan sosial baik itu formal dan non formal seperti mendirikan Masjid untuk sarana ibadah, tahfidzul Qur'an dan gedung sarana pendidikan. Dari hal tersebut telah banyak mendapatkan respon positif baik dari kalangan pemerintahan maupun masyarakat.

\section{Pendapat Pemerintah}

Pegawai kelurahan Maccini Sombala dan jajarannya sangat merespon positif kehadiran Muslim Tionghoa menurut salah seorang pegawai yang bertugas sebagai direksi kepala Kasih pemerintahan Kelurahan Maccini Sombala:

"Alhamdulillah selama ada Muslim tionghoa dan mendirikan Masjid lancar orang pergi sembahyang, banyak singgah di situ kalau lalu-lalang orang Islam langsung shalat pada hari jum'at biar bukan hari jum'at magrib, dzuhur, azhar, Alhamdulillah sangat bagus, dan masjid itu menjadi Iconnya kelurahan Maccini Sombala. Kita sangat berterimakasih banyak, lancarnya anak-anak disini masuk di pondoknya itu sangat membantu, kita sangat-sangat berterimakasih sekali atas itu semua." 17

Menurut pemerintah setempat bahwa didalam islam kita dianjurkan untuk berfastabikul khaerat, saat mereka mendirikan saran pendidikan itu adalah upaya dan usaha dari Muslim Tionghoa untuk memajukan masyarakat Muslim, terkait dengan isu bahwa mereka adalah antek-antek orang cina, hal tersebut suatu hal yang wajar karena saat ini dalah musim politik, dan untuk menjatuhkan wibawah dari Muslim tionghoa, pasti banyak pihak-pihak yang tidak bertanggung jawab. Salah seorang muslim tionghoa juga banyak yang mendaftar caleg seperti Pak Haji Suhardi yang menjadi Calon legislatif dari Fraksi PKB di DAPIL 1 (kecamatan Somba Opu) Gowa, nah olehnya itu mereka akan mereka akan mencari-cari cela agar menjatuhkannya ditenga masyarakat, seperti menyebar isu-isu seperti ini.

17 Nur Lia (45 Tahun), Direksi kepala Kasih pemerintahan Kelurahan Maccini Sombala"Wawancara", Makassar pada tanggal 03 Oktober 2018. 


\section{Pendapat Masyarakat Pribumi}

Kedatangan etnis Tinghoa ini sama sekali tidak ada minat untuk menguasi atau menjajah, semata-mata hanya untuk berdagang, sehingga mereka bisa diterima oleh masyarakat setempat dengan baik. Hubungan harmonis ini akhirnya berlanjut dengan adanya orang-orang Tionghoa yang pada tahun-tahun selanjutnya tinggal lebih lama bahkan berdomisili dan berasimilasi di Makassar ditambah lagi dengan semakin banyaknya orang-orang Tionghoa masuk dan memeluk Islam maka persauadaraan sesama umat Islam semakin terikat dan terjalin dengan baik

Masyarakat setempat sangat mengapresiasi keberadaan dan kegiatan-kegiatan yang dilaksanakan Muslim di Makassar, Menurut Mahasiswa yang sering sholat di masjid Muhammad Cheng Hoo mengatakan bahwa:

Terkait dengan pendidikan yang diselenggarakan Muslim tionghoa "saya kira cukup bagus dan perlu diapresiasi yang sudah membantu pendidikan formal untuk menjadikan muda-mudi muslim menjadi penghafal quran dan paham agama, karena kita lihat to, bukannya mengucilkan pendidikan formal tapi faktanya memang seperti itu, saya pernah mengajar dilembaga formal, tidak usa saya bilang namanya, saya tes hafalannya ternyata kebanyakan mereka itu dapat ilmu atau hafalan yang banyak itu ternyata dari lembaga yang memang khusus untuk menghafal Al-qur'an begitu, jadi dengan adanya pendidikan Islam yang dilakukan oleh Muslim Tionghoa saya sangat setuju dan mengapresiasi dan perlu untuk disupport". ${ }^{18}$

Terkait dengan isu bahwa Muslim tionghoa adalah antek-antek orang cina untuk menguasai Indonesia menurut masyarak pribumi itu hanyala halusinansi atau produk yang ditunggangi oleh para pelaku politik untuk mengucilkan Muslim tionghoa.

Kehadiran Muslim tionghoa ditengah-tengah masyarakat pribumi khususnya dimakassar tidak menjadi kekhawatiran sebab Muslim Tionghoa sudah menjadi bagian penting bagi penduduk, kehadiran mereka bukan baru tapi telah berlangsung ratusan tahun yang lalu bahkan telah menjaling hunbungan kekeluargaan dan pernikahan dengan masyarakat setempat

\section{Muslim Tionghoa Makassar dan Negara China}

Kota Makassar merupakan kota yang metropolitan, masyarakatnya majemuk dan beraneka ragam agama, suku, ras, etnis, dan antargolongan. Termasuk pula kebudayaan dan agamanya. Selain penduduk pribumi terdapat pula sejumlah penduduk etnis pendatang. Di antara etnis pendatang adalah etnis Tionghoa, Orang-orang keturunan Tionghoa sudah beratus tahun berdomisili di Indonesia, sebagian besar orang Tionghoa dilahirkan dan dibesarkan di Indonesia bahkan sebagian besar dari

${ }^{18}$ Firmansyah (25 Tahun), jamaah masjid Muhammad Cheng Hoo,"Wawancara", di Makassar pada tanggal 02 Oktober 2018 
mereka sudah tidak tahu berbahasa China, hal ini tidak menjadi kekhawatiran bagi masyarakat pribumi.

"Yang perlu kita Khawatirkan itu ya China-china Komunis, yang punya modal besar, belakangan ini kan kita kenal ada teori Proksy, kepentingan Negaranegara lain yang dilakukan dinegara-negara tertentu yang tidak nampak, itu yang menjadi ke khawatiran orang, karena sudah ada contohnya singapur dulunya itu melayu diambil dengan kebudayaan cina dengan apa, maka menjadi kekhawatiran, lagian kan china itu sudah mengalami luapan penduduk 1,7 Milliar dengan luapan penduduk ini dikhawatirkan suatu Negara itu tidak bisa menghidupi rakyatnya, bertolak dari itu, pemerintah yang betul-betul memikirkan kelangsungan hidup rakyatnya dia musti cari dimana di musti hidupi, nah Indonesia ini yang dikenal sebagai Nusantara Jamrud Katulistiwa maka semua bisa hidup, yang perlu dikhawatirkan yang baru datang dari China dan mencari kerja di Indonesia seperti di Morowali, beda dengan mata Sipit yang tumpah daranya di Sini, neneknya disini”. ${ }^{19}$

Bahkan etnis Tionghoa dikota Makassar dengan Negara China sama sekali tidak ada hubungan terstruktur yang ada hanya hubungan terkultur atau yang bersifat kebudayaan hal ini dipertegas oleh Lenni salah satu anggota PSMTI pada dialog kebangsaan, di Hotel The Rinra, Jl Metro Tanjung Bunga, Rabu (23/8/2017). Dialog yang menghadirkan Pangdam XIV Hasanuddin Mayjen Agus Surya Bakti, Wakapolda Brigjen Guntur, Kepala Bappeda Sulsel Jufri Rahman.

Penyebutan China itu sama halnya dengan pelecehan etnis Tionghoa. Dari sejarahnya, kalimat China adalah sebutan para penjajah kepada etnis Tionghoa. Olehnya itu, para etnis Tionghoa merasa bahwa istilah itu tak perlu di ungkap. Tolong dan dengan sangat saya meminta Pak Jendral (Pangdam) dan Wakapolda untuk mempertegas ke publik soal meniadakan kata China bagi etnis Tionghoa, kami bukan China. $^{20}$

Setelah mengutarakan pernyataan ini para hadirin menyambutnya denga tepuktangan yang meriah kata Lenni, sembari disambut tepukan tangan peserta. ${ }^{21}$

Dari hasil kajian diatas penulis berpendapat bahwa erkait dengan isu bahwa Muslim tionghoa adalah antek-antek orang cina untuk menguasai Indonesia, itu hanyala halusinansi atau produk yang ditunggangi oleh para pelaku politik untuk mengucilkan Muslim tionghoa.

\section{KESIMPULAN.}

Pendidikan formal yang didirkan oleh Muslim Tionghoa yaitu SDIT Muhammad Cheng Hoo Sul-sel yang terletak di Jalan Tun Abd Razak Gowa, namun

\footnotetext{
${ }^{19}$ Pimori Kahar Muang (57 Tahun), Jamaah Masjid Muhammad Cheng Hoo"Wawancara", Makassar pada tanggal 05 Oktober 2018.

${ }^{20}$ Dialog kebangsaan, di Hotel The Rinra, J1 Metro Tanjung Bunga, Rabu (23/8/2017).

${ }^{21}$ Dialog kebangsaan, di Hotel The Rinra, Jl Metro Tanjung Bunga, Rabu (23/8/2017).
} 
saat ini belum berjalan karena masih proses pendirian gedung dan diprediksikan akan digunakan pada tahun 2021. Selain pendidikan formal, para Muslim Tonghoa juga mendirikan lembaga pendidikan non formal yang terdiri dari; Pondok Tahfidzul Qur' an Muhammad Cheng Hoo Makassar, dan Pendidikan dan pembinaan Muallaf.

Tantangan yang dihadapi untuk mendirikan lembaga belajar ini adalah terbatasnya bangunan yang dapat digunakan dalam proses belajar mengajar, serta belum tersedianya asrama tetap bagi muallaf yang ingin belajar islam lebih dalam. Peluang program tahfidzul Qur'an ini diantaranya: 1) Program tanpa beban biaya, hadirnya Muslim Tionghoa ditengah-tengah Masyarakat pribumi, menjadi angin segar bagi penduduk setempat dengan terlaksananya program Tahfidzul ini tanpa membebani biaya bagi para santri yang mondok untuk menghafal. 2) Donatur tetap, Program tahfidzul qur'an ini dibantu oleh Ibu Ramlah Aqsa beliau merupakan donator tetap untuk pelaksanaan program tahfidzul Qur'an ini yang telah berlangsung kurang lebih dua tahun dan juga dari PITI Makasassar. Peluang program pendidikan dan pembinaan Mualla ini diantaranya: 1) Dilaksanakan oleh Muallaf, Hadirnya pendidikan dan pembinaan Muallaf yang dilaksanakan oleh Muslim Tionghoa menjadi alternatif dan memberikan ciri khas karena umumnya yang menjalankan program ini adalah para Muallaf itu sendiri khususnya Muslim tionghoa, olehnya itu para muallaf yang baru masuk Islam tidak ragu-ragu untuk berbaur dan berproses pada program ini bahkan pemateri dalam hal ini adalah dari Muallaf itu sendiri. 2) Pendidikan dan pembinaan dilaksanakan secara gratis, banyaknya Muallaf-muallaf yang berekonomi menegah keatas yang masuk Islam mereka banyak memberikan bantuan dalam menjalankan program ini utamanya dari PITI itu sendiri, sehingga untuk memenuhi kebutuhan pelaksanaan peserta tidak dibebani biaya.

Masyarakat setempat sangat mengapresiasi keberadaan dan mensupprot kegiatan-kegiatan yang dilaksanakan Muslim Tionghoa di Makassar, Terkait dengan isu bahwa Muslim Tionghoa adalah antek-antek orang cina untuk menguasai Indonesia menurut masyarak pribumi itu hanyala halusinansi atau produk yang ditunggangi oleh para pelaku politik untuk mengucilkan Muslim tionghoa.

\section{DAFTAR PUSTAKA}

Abdul Halim (40 Tahun), Sekretaris panitia pembangunan SPIT Muhammad Cheng Hoo Sul-sel, Wawancara, Makassar pada tanggal 03 Oktober 2018

Aftonul Afif, Menjadi Indonesia, Pergulatan Identitas Tionghoa Muslim Indonesia. Yogyakarta: Parikesit Institut, 2010.

Badaruddin Basir (38 tahun), Sekretaris Masjid Muhammad Cheng Hoo Makassar "Wawancara", Makassar pada tanggal 28 September 2018

Badudu, Kamus Besar Bahasa Indonesia Edisi Lengkap, Jakarta : Cijago Pers, 2002. 
Baidhawy Zakiyuddin, Agama dan Pluralitas Budaya Lokal. Surakarta: Univesitas Muhammadiyah Surakarta, 2003.

Budiono K, Kebinekaan Masyarakat Indonesia Suatu Problematik Filsafat Kebudayaan. Jakarta:Grasindo, 2000.

Dialog kebangsaan, di Hotel The Rinra, Jl Metro Tanjung Bunga, Rabu (23/8/2017).

Firmansyah (25 Tahun), jamaah masjid Muhammad Cheng Hoo,"Wawancara", di Makassar pada tanggal 02 Oktober 2018

H. Abdul Karim (Oey Tjeng Hien), Mengabdi Agama, Nusa, dan Bangsa: Sahabat Karib Bung Karno, Jakarta: Gunung Agung, 1982.

Hasil Muktamar Nasional 3 PITI", Hotel Equator Surabaya, 2-4 Desember 2005, h. 14.

Ismail (22 tahun), jamaah Masjid Muhammad Cheng Hoo,"Wawancara", di Makassar pada tanggal 03 Oktober 2018

Junus Jahja, Non pri di mata Pribumi.Jakarta: Yayasan Tunas Bangsa, 1991.

Kementrian Agama RI, Al-Qur'an dan Terjemahnya, Bandung: CV Penerbit J-ART, 2004

Langggulung, Hasan. Asas-Asas Pendidikan Islam. Jakarta. PT. Pustaka Al Husna Baru. 2008.

Legiran (27 Tahun, Koordinator Program Tahfidzul Qur'an Masjid Muhammad Cheng Hoo Machasin, Islam Dinamis, Islam Harmonis. Yogyakarta: LKIS, 2012

Muhammad Zain Fong (41 Tahun), Ketua Umum Masjid Muhammad Cheng Hoo Gowa"Wawancara", di Makassar pada tanggal 28 September 2018

Nur Lia (45 Tahun), Direksi kepala Kasih pemerintahan Kelurahan Maccini Sombala”Wawancara", Makassar pada tanggal 03 Oktober 2018.

Pimori Kahar Muang (57 Tahun), Jamaah Masjid Muhammad Cheng Hoo"Wawancara", Makassar pada tanggal 05 Oktober 2018.

Sukmadinata Syaodih. Metode Penelitian Pendidikan. Bandung: PT.Remaja Rosdakarya. 2007.

Sulaiman Gosalam (49 Tahun), Ketua PITI Pertama Makassar, Wawancara, Makassar pada tanggal 05 Oktober 2018

Zulhaq (16 Tahun), Santri Program tahfidzul Qur'an Masjid Muhammad Cheng Hoo Makassar "Wawancara", Makassar pada tanggal 04 Oktober 2018. 